\title{
Evidence of weak genetic differentiation of Striga gesnerioides populations collected in Senegal: possible relationship with traditional cowpea seed management
}

\author{
Amidou N'Diaye - Dolou Charlotte Tonessia • \\ Loïc Le Cunff · Perla Hamon · Serge Hamon
}

Received: 4 April 2008 / Accepted: 13 May 2009

(C) Springer-Verlag 2009

The Chief Editor of "Theoretical and Applied Genetics" in agreement with the publisher hereby retracts this article. The article is retracted due to disputed authorship and severe omissions in the information of collaborators about the publication. The authors have agreed to the retraction of this article.

\footnotetext{
A. N'Diaye $(\square) \cdot$ L. Le Cunff

INRA, UMR DIAPC, 2 Place Pierre Viala,

34060 Montpellier Cedex 01, France

e-mail: ndiayea@supagro.inra.fr

D. C. Tonessia

CERAAS, BP 3320, Thiès-Escale, Senegal

P. Hamon $\cdot$ S. Hamon

IRD, UMR DIAPC, 911 Av Agropolis, BP 64501,

34394 Montpellier Cedex 5, France
} 